\title{
Monthly variations in physico-chemical characteristics of water, MPN index and zooplankton of Devak stream, at Shiv temple complex, Udhampur, Jammu ( J \& K), India
}

\author{
S. P. S. Dutta \\ UGC Emeritus Fellow, Department of Environmental Sciences, University of Jammu, Jammu- 180006 (J\&K), \\ INDIA \\ E-mail: duttasps@gmail.com
}

Received: November 11, 2014; Revised received: December 01, 2014; Accepted: December 14, 2014

\begin{abstract}
Water quality characteristics, MPN index $/ 100 \mathrm{ml}$, and zooplankton of sacred Devak stream, Udhampur were analyzed during February, 2010 to January, 2011. Various water quality parameters showed a well marked seasonal variation including MPN index/100 ml which remained above 240 during all the observations. Zooplanktons comprising of 46 species showed qualitative dominance of protozoa (33 species) followed by rotifera ( 7 species), annelida ( 2 species) and insecta (1 species), water nematoda, turbellaria (1 species) and cysts. Zooplankton was qualitatively and quantitatively poor/absent during monsoon floods (June to September) and was diversified and rich during February to May. Comparison of water utility parameters and MPN count/100 ml with national and international agencies suggested that water of this stream was not fit for consumption.
\end{abstract}

Keywords: Devak stream, Most probable number, Physico-chemical parameters, Water quality, Zooplankton

\section{INTRODUCTION}

The expanding human population, industrialization, extensive agricultural practices and developmental activities discharge massive amount of waste water into the water bodies and has resulted in deterioration of water quality. The impact of these anthropogenic activities has been so extensive that many water bodies have lost their self-purification capacity to a large extent. This has resulted in scarcity of portable water supply and loss of biodiversity in water bodies. The health and well being of the human race is closely tied up with a quality of water used (Sharma et al., 2010). Therefore, there is a grown recognition and need that aquatic water bodies must be sustained so that they may support human life. In recent past various studies have been undertaken on the effect of waste water on physico-chemical and biological characteristics of lotic water bodies (Sah et al, 2000; Sharma et al, 2010; Saron and Bijen Meitei, 2013 and Patel and Singh, 2014). In Udhampur district of Jammu region are present a good number of widely distributed fresh water streams. However, there is no record of hydro biological study of any lotic water body of the said district. Keeping all this in view, the present investigation was conducted to study the monthly variations in physico-chemical characteristics of water, MPN index $/ 100 \mathrm{ml}$ and zooplankton of sacred Devika stream, at Shiv Temple Complex, Udhampur, Jammu, and has been described.
Topography of study area :Sacred Devika stream flows through the Udhampur city and has its origin from Nadda Gali spring. It joins Chowka nullah, at Boni Sung, before entering river Tawi (Pandita, 2005). It had quality water, a few decades ago, as a large number of springs were joining the stream at various places. Construction of buildings and widening of roads, along its sides, have obstructed underground water channels and there is decline of springs and spring water discharge. Deforestation in the catchment has further reduced rain water infiltration and springs and spring water discharge in the catchment. The stream has its religious importance and is called as Gupt Ganga. There is an ancient Shiv temple and has a good number of active springs in the area. People after burning dead bodies take bath from spring water. Due to religious belief, after burning of dead bodies, at cremation ground near Shiv Temple Complex, Udhampur, ashes are not collected and ultimately sink underground. On Baisakhi festival people from the adjacent villages and even from Jammu city visit the temple and some take bath in Devika stream. Some people even drink and carry water for use during different occasions. Due to expansion of city there is entry of untreated sewage drains including hospital waste, in the stream at various places. Its water quality is rapidly deteriorating and during summer months water has offensive smell. Flower garlands, religious worship waste materials during Navratras and other seasons are dumped into this stream. 


\section{MATERIALS AND METHODS}

For the present limnological study, at one station near Shiv Temple complex, monthly water sample was collected in plastic containers and analyzed following standard methods (APHA, 1998). For DO analysis, water samples were collected in BOD bottles and fixed at the spot. Water samples for BOD analysis were collected in sterilized BOD bottles. At the time of water sampling air and water temperature was recorded by mercury bulb thermometer $\left({ }^{\circ} \mathrm{C}\right)$, depth with a graduated meter rod and transparency by Secchi disc (Welch, 1948). Water samples, after sampling, were analyzed within two hours in the laboratory. For MPN index/100 ml, water samples were collected in sterilized BOD bottles and analyzed by standard methods (APHA, 1998).Zooplanktonic samples were collected by filtering five liters of water through a planktonic net (No. 25) in labeled tubes and identified (Nair et al., 1971; Pennak, 1978; Dutta, 1983; Kudo, 1986, Battish, 1992 and Edmondon, 1992); and counted in Sedgewick rafter counting cell.

\section{RESULTS AND DISCUSSION}

The results of water quality characteristics are given in Table 1. Due to shallowness and continuous flow, water temperature $\left(13-32^{0} \mathrm{C}\right)$ closely followed the air temperature $\left(14^{0}-31^{\circ} \mathrm{C}\right)$. Temperature remained high during April-July followed by a decline thereafter. Air and water temperature remained very low during winter viz. December and January. Depth in shallow Devika stream varied between $37 \mathrm{~cm}$. (February) to $100 \mathrm{~cm}$ (July). It remained comparatively high during monsoon viz. June and July. Transparency, which varied between $20 \mathrm{~cm}$ (April) to $75 \mathrm{~cm}$ (July), was low during February to May. Turbidity and suspended matter in Devika stream varied between 6.5 to $350.2 \mathrm{NTU}$ and $15-700 \mathrm{mg} / \mathrm{l}$, respectively. These were comparatively high during February- May. April maximum record of turbidity and suspended matter and minimum value of transparency (Table-1) is attributed to week long celebrations of Baisakhi festival and congregation of large number of devotees taking bath near the temple and immersing various types of materials into the stream. During this period of festival temporary shops are found everywhere. Contrary to the April minimum record of transparency and highest value of turbidity and suspended matter in Devika water, such observations for these parameters in subtropical lotic waters of Jammu have been noticed during monsoon (Dutta, 1978, 2012; Dutta et al., 2001; Zutshi, 1992; Koul, 1999, Sharma, 1999, Sharma, 2009 and Rathore, 2009). Due to absence of carbonate and perennial free $\mathrm{CO}_{2}$ presence (8.51-38.94 mg/l), $\mathrm{pH}$ showed a narrow annual variation between 6.71-7.54. An inverse relationship of $\mathrm{pH}$ with free $\mathrm{CO}_{2}$ (Welch, 1951; Hutchinson, 1957 Schwoerbell, 1970; Cole, 1975; Reid and Wood, 1976; Goldman and Horne, 1983; Jhingran, 1991 and Wetzel, 2000) may explain February to June low $\mathrm{pH}$ record during high free $\mathrm{CO}_{2}$ presence in water. Free $\mathrm{CO}_{2}$ in Devak stream remained comparatively high during February - June and coincided with presence of large quantities of sewage during summer reduced spring water discharge and increased microbial decomposition of dead organic matter at high water temperature. A direct relationship of BOD and microbial decomposition of dead organic matter and inverse relationship of free $\mathrm{CO}_{2}$ and oxygen and temperature and oxygen solubility in water may explain February to May high record of $\mathrm{BOD}$ and free $\mathrm{CO}_{2}$ and low value of $\mathrm{DO}$ in Devika stream water.

Presence of variable amount of sewage and biodegradable dead organic matter during different months may explain a wide annual variation in DO (0.83-8.42 mg/l) and BOD (2.33-258 mg/l). June to January increased water flow in Devika stream caused by monsoon rains (June - September), post monsoon increase in springs and spring water discharge (September-November) and winter rains (December and January) diluting sewage water may explain high record of DO and low observation of free $\mathrm{CO}_{2}$ and BOD. Increased oxygen solubility at low temperature and reduced microbial activity during winter may also explain December and January rise in DO and low observation of free $\mathrm{CO}_{2}$ and BOD in Devika stream water.

Due to variable monthly water discharge and sewage flow in Devika stream, various water quality parameters like conductivity ( 0.301-.718 mS), total dissolved solids ( $210-322 \mathrm{mg} / \mathrm{l})$, salinity (0.3-0.7 ppt), bicarbonate (231.95-521.98 $\mathrm{mg} / \mathrm{l})$,chloride (28.78-48.07 $\mathrm{mg} / \mathrm{l})$, calcium (44.35-101.06 mg/l), magnesium (10.54-18.75 $\mathrm{mg} / \mathrm{l})$, total hardness $(158-316.4 \mathrm{mg} / \mathrm{l})$, sodium $(15.6-$ $51.1 \mathrm{mg} / \mathrm{l})$, potassium $(4.10-12.1 \mathrm{mg} / \mathrm{l})$ and phosphate (0.081-0.620 mg/l) have shown irregular wide variations (Table 1). Comparatively, a high record of conductivity, total dissolved solids, salinity, bicarbonate, chloride, calcium, magnesium, total hardness and phosphate is seen during February to June and is ascribed to reduced water flow in Devika stream, presence of large quantities of sewage and accelerated microbial decomposition of dead organic matter, at high summer temperature. Verma and Dalela (1975), Sharma et al. (1989) also noticed summer rise in BOD and various anions and cations in polluted lotic waters. Heavy metals like chromium, nickel, zinc and lead are below the detectable limit in water (Table 1).

Comparison of various water quality parameters of Devika stream with national and international standards of drinking water quality (Table 2) clearly reveals that levels of turbidity, electrical conductivity, free $\mathrm{CO}_{2}, \mathrm{DO}, \mathrm{BOD}$, bicarbonates, calcium , total hardness and phosphate, during different months, are not within the permissible levels of drinking water standards. Devotes, therefore, should be advised not to use this water.

Quantitative analysis of microbes: In Devika stream, MPN index per $100 \mathrm{ml}$ was $\geq 240$ throughout 


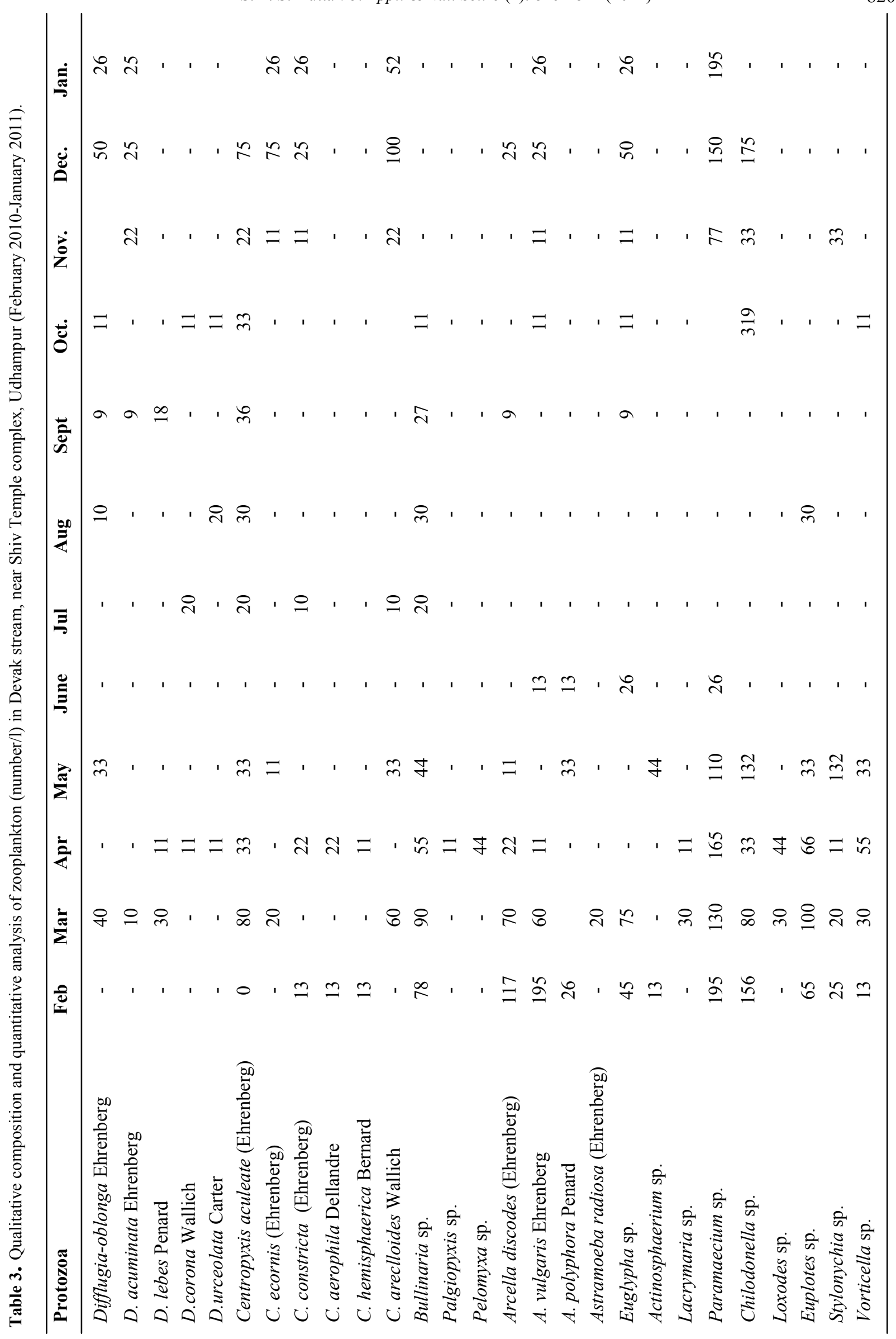


the year viz. February, 2010- January, 2011. This indicates contamination of water by human excreta along with sewage entering at various places. In the catchment of the stream, there is open defecation and stray animals move and graze in open. Human and animal excreta flow into the stream during rains. According to BIS (1991) and WHO (1991) allowable limits of coliforms is $10 / 100 \mathrm{ml}$ in drinking water. As per CPCB (1992) recommendations water containing total coliform above $50 / 100 \mathrm{ml}$ is unsuitable for drinking purpose without conventional treatment and disinfection. Based on the presumptive coliform count $/ 100 \mathrm{ml}$ classification by BMH (1957) viz. excellent $(0 / 100 \mathrm{ml})$, satisfactory $(1-3 / 100 \mathrm{ml})$, suspicious $(4-10 / 100 \mathrm{ml})$ and unsatisfactory $(>10 / 100 \mathrm{ml})$ for drinking water, the water quality of Devika stream comes under the category of unsatisfactory viz $>10 / 100 \mathrm{ml}$. Thus, based on the presence of coliforms $(>240 / 100 \mathrm{ml})$, water of Devak stream is not suitable for drinking, bathing, washing etc. Therefore, devotees are advised not to use this water on any occasion.

Zooplankton: Zooplankton, qualitatively, comprising of 46 species has shown the presence of 25 species of Protozoa viz. nineteen species of Rhizopoda (Difflugia oblonga, D. acuminata, D. lebes, D. corona, D. urceolata, Centrophyxis aculeata, C. ecornis, C. constricta, C. aerophila, C. hemispherica, C. arcelloides, Arcella discoides, A. vulgaris, A.polyphora, Bullinaria sp., Plagiopyxis sp., Pelomyxa sp., Astramoeba radiosa. Euglypha, Actinosphaerium sp. and Lacrymaria sp., seven species of Ciliata Paramaecium sp., Chilodonella sp. Loxodes sp., Euplotes sp., Stylonychia sp., Vorticella sp. and Carchesium sp. ), two species of Suctoria (Podophrya sp. and Tokophrya sp.), three species of Mastigophora (Euglena acus, E. virides and Phacus sp); 9 species of Rotifera (Philodina sp. , Rotaria sp., Brachinus sp., Monostyla sp., Notholca sp., Platyias sp. and Lepadella sp. ), 2 species of Annelida (Aelosoma sp. and Chaetogaster sp.), 1 species of Arthropoda (Chironomus sp.), 1 species of Turbellaria (Planaria sp.), water nematodes and cysts (Table 3 ). Zooplanktonic composition of Devika stream is different from the findings of earlier workers. Vass et al. (1977) noticed 5 species of Protozoa, 9 species of Rotifera, 6 species of Cladocera and 4 species of Copepoda from the river Jhelum, Kashmir. Dutta (1978) noticed Protozoa (4 genera), Rotifera ( 5 genera), Cladocera (9 genera) and Copepoda (4 genera) and nauplius larva from Gadigarh stream, Jammu. Zutshi (1992) analyzed zooplankton of river Tawi and reported 6 species of Protozoa, 3 species of Rotifera, 2 species of Cladocera and 3 species of Copepoda. Ephemeroptera, Diptera, Oligochaeta, and Nematoda at the non- polluted Nagrota bypass station of river Tawi. At the polluted Bhagwati nagar station she noticed Protozoa (11species), Rotifera (6species), Copepoda (1species), Ostracoda, Oligochaeta, Ephemeroptera, Nematoda, and Arachnida. Sharma (1999) observed Protozoa (84 species), Rotifera (37 species) and Crustucea (15 species) from Behlol nullah, Jammu. Rathore (2009) analysed zooplanktons of Ujh river, Kathua, Jammu, and noticed Prozoa ( 25 species), Rotifera (12 species), Oligochaeta (1species), water Nematoda and Ephemeroptera. Dutta and Verma (2010) observed fourteen species of Protozoa, one species of Porifera, and one species of Copepoda from the river Chenab, Jammu

Protozoans and rotifers abundance in sewage polluted Devika stream is in agreement to the observations for one or the other species in degraded water by Verma and Dalela (1975), Vasisht and Sra (1979), Vasisht (1984), Kachroo and Suri ( 1987), Saxena and Mishra (1990), Ricci (1995) and Sharma (1999). Dogra and Kaw (1989) mentioned that protozoa constitute biological pollutants of aquatic ecosystem in various polluted waters. Predominance of protozoans and subdominance of rotifers observed in polluted in this polluted stream may be due to their tolerance and multiplication in euryhaline polluted waters; and presence of large quantities of detritus, organic matter richness and dense bacterial population on which protozoans and rotifers feed (Kudo, 1986 and Slathia and Dutta, 2013); sewage contamination resulting in oxygen decline and elimination of sensitive crustacean species; absence of planktivorous crustaceans and fish and fish larvae feeding on protozoans and rotifers and absence of any allogenetic lotic and lentic water source of plankton.

Among various species of protozoans there is dominance of Rhizopoda and may be due to their periphytonic growth and automatic release into the water or washing off from the supports by water movements (Young, 1945). Occurrence of benthic annelids, insects, water nematodes and planarians, among zooplanktonic samples, is because of disturbance of bottom sediments caused by flowing water and devotees and children bathing in water.

Presence of cysts, among zooplanktonic samples, clearly supports water contamination by human excreta and is the result of open defecation along the sides of sewage drains and Devika stream by people lacking toilet facilities. Although some people have toilet facilities but lack soaking pits. As such water from septic tanks directly flow into the drains and add cysts, eggs and larvae. In many houses even septic tanks are absent and there is direct flow of excreta into drains joining the Devika stream.

Qualitatively, in this stream, all the zooplanktonic species showed their irregular monthly record (Table 3 ). Jhingran (1991) also documented seasonal planktonic association and explained that certain planktonic forms apparently disappear at the specific periods and reappear during other period. Such temporary disappearances are due to the fact that the species concerned become scare or occur as spores or resting eggs and are not easily detectable. On the return of favourable conditions young ones hatch from the resting stages and 
multiply, grow and show their presence in the palnktonic samples. This seasonal zooplanktonic association of various species may be attributed to irregular changes in water characteristics caused by fluctuations in sewage discharge, springs and spring water discharge, rains etc. Quantitatively total zooplankton protozoans, rotifers, turbellarians, nematodes, annelids, arthropods and cysts in Devak stream, at Shiv Temple Complex station, varied between 104-3759n/1, 78-1170 n/l, 0-562 $\mathrm{n} / 1,0-65 \mathrm{n} / 1,0-99 \mathrm{n} / 1,0-60 \mathrm{n} / 1$ and 0-2004 n/1 respectively (Table 3 ).

Zooplanktonic diversity and density is low during monsoon floods (June to September). This is in accordance to the earlier observations of Dutta (1978), Dutta and Verma (2010), Dutta et al. (1990), Zutshi (1992), Sharma (1999), Sharma (2009) and Rathore (2009).

Warming of water, optimum water flow and a good availability of detritus and bacteria and increased summer multiplication may explain February to May qualitative richness and quantitative increase in zooplankton (Table 3). A similar type of correlation has been drawn by Sanjev and Sharma (1995), Katiyar (1995), Dutta and Verma (2010), Dutta et al. (1990 and 1991) and Sharma (1999) .

Comparison of water quality parameters, and MPN index/100ml count with National and International Standards clearly reveals that water of Devika stream, at Shiv temple complex, Udhampur, is highly polluted. Presence of cysts in analyzed water samples further supports water contamination by human excreta. There are reports of skin problems to the devotees taking bath in the polluted water of this stream. As such, devotes are advised not to use / consume this water on any occasion.

\section{Conclusion}

From the present monthly water quality and biological analysis (MPN Index $/ 100 \mathrm{ml}$ ) it is concluded that water of Devika stream is not fit for consumption. Taking into consideration the sentiments of devotees attached to this sacred stream, authorities should immediately take some steps to check the entry of sewage water into the stream and develop spring sanctuaries in the catchment to revive some important springs in the area to maintain its optimum water flow and water quality.

\section{ACKNOWLEDGEMENTS}

I extend my thanks to UGC for awarding Emeritus fellowship, Head, Deptt. of Environmental Sciences, University of Jammu, Jammu, is acknowledged for providing necessary facilities in the Department.

\section{REFERENCES}

APHA (1998). Standard methods for examination of water and waste water. $20^{\text {th }}$ ed. American Public Health Association, New York.

Battish, S.K. (1992). Freshwater zooplankton of India. Oxford and IBH Publishing Co. Pvt. , New Delhi.
BIS (1991). Indian standard specifications for drinking water IS: 10500-91 (Bureau of Indian Standards) New Delhi: 1-4.

BMH (1957). The bacteriological examinations of water supplies. Report No. 7, British Ministry of Health, London, U.K.

Cole, G.A. (1975). A text book of Limnology. The G.V. Mosby company. Saint Louis. 3283 pp.

CPCB (1992). A system for surface water classification, Indian. Central Pollution Control Board, New Delhi.

Dogra,S. and Kaw,J.L. (1989). Industrial effluents and aquatic ecosystem : A toxicological overview in Manual.

Dutta, S.P.S. (1978). Limnology of Gadigarh stream (Miran Sahib, Jammu) with special reference to consumers inhabiting the stream. Ph. D. Thesis, University of Jammu, Jammu.

Dutta, S.P.S. (1983). On some fresh water Rhizopoda from Jammu Part-1, J. Univ. Review (Science), 1: 91-94.

Dutta, S.P.S (2012) Limnology of the river Chenab at Akhnoor, Jammu. Project Report submitted to the UGC, New Dehli.

Dutta, S.P.S. , Zutshi, N and Puri, A. (1990). Ecology of protozoans from some pools present along the sides of the river Tawi, near Nagrota, Jammu. J. Hydroboil., 6 (1): 19-24.

Dutta, S.P.S. , Kumar, S. and Kumari, V. (1991). Seasonal fluctuations in protozoans in Kunjwani pond, Jammu. Geobios new Reports. 10 : 121-124

Dutta, S.P.S., Bali, J.P.S., Kour, H. and Sharma, I.D.(2001). Hydrobiology of river Basantar an important tributary of the river Ravi. J. Aquatic Biol., 16(1-2): 4144.

Dutta, S.P.S., Malhotra, Y.R., Gupta, S.C. and Shekhar, C. (1999). Abiotic limnology and some biological aspects of Schizothorax richardsonii (Gray and Hard) inhabiting Neeru nullah, Bhaderwah, District Doda ( J and K). J. Aqua. Biol. , 14(1-2): 39-42.

Dutta, S.P.S. and Verma, K.K. (2010). Zooplanktonic analysis of the river Chenab at Akhnoor, Jammu. The Ecoscan, 4(1): 123-28.

Edmondson, W. T. (1992) Fresh water biology. Jhon Willy and Sons, Newyork. 1248pp

Goldman, C.R. and Horne, A.J. (1983).Limnology. Mc. Graw Hill International Book Company, New Delhi.

Hutchinson, G.E. (1957). A Treatise on Limnology.Vol. I H.J. Wiley., New York: 1015 pp.

Jhingran, V.G. (1991). Fish and Fisheries of India. Hindustan Publishing Corporation, Delhi: 727 pp.

Kachroo, P. and Suri, B.L. (1987). A decade of pollution in Dal Lake (Kashmir ) Key note address delivered at $8^{\text {th }}$ session of AFB and Symposium at Jammu, Academy of Environmental Biology.

Katiyar, S.K. (1995). Limnological studies on Bhopal lakes 1: Prtozoan fauna of polymictic and homothermal lake. J. Freshwater Biol., 7(3): 159-163.

Koul, V. (1999). Effect of industrial wastes and sewage on abiotic and biotic (macrobenthos and fish) components of Behlolnullah, Jammu. Ph. D. Thesis, University of Jammu, Jammu.

Kudo, R.R. (1986). Protozology. Published by Books and Periodical Corporation (India): $1174 \mathrm{pp}$.

Nair, K.N. , Das, A.K. and Mukherjee, B.N. (1971). On some freshwater Rhizopoda and Helizoa (Protozoa) 
from Calcutta and its environs. Part I. Rec. Zool. Surv. , India, 65 (1-4): 1-16.

Pandita, R.N. (2005). Survey report on fisheries resources of district Udhampur, Department of Fisheries, J \&K Government.

Patel, S and Singh, S. (2014). Seasonal variation of phytoplankton and zooplanktonin Beehar river, Riwa (M.P.) India. Journal of Applied Research, 4(9): 558560

Pennak, R.W. (1978). Fresh water Invertebrates of the United States. IInd ed. John Wiley and Sons, New York: $803 \mathrm{pp}$

Rathore, V. (2009). Hydrobiology of Ujh river, Kathua ( J \& K). Ph. D Thesis. University of Jammu, Jammu.

Reid, G.K. and Wood, R.D. (1976). Ecology of Inland Waters and Estuaries. D. Van Norstrand Company, New York.: $485 \mathrm{pp}$.

Ricci, N (1995). Pollution and Biomonitoring. B.C. Rana (Ed.) Tata Mc Graw Hill Publishing Company Ltd. Protozoa Bioindicators of Env. Monitoring and Pollution on Control : 240-269.

Sah, J. P., Sah, S. K. Acharya , P., Pani, D. and Lance, V. A. (2000). Assessment of the water pollution in the Narayarni river, Nepal. Intt. J. Ecol and Environ. Sci., 26: 235-252.

Saxena, D.N. and Mishra, S.R. (1990). On the planktonic fauna of industrial waste water from Birlanagar industrial complex, Gwalior, India. Geo bios new Reports. 9: 186-188.

Sanjeev, L.R. and Sharma, U.P. (1995). Community structure of plankton and their periodicity in Kawar lake, wetland, Begusarai, Bihar. II Zooplankton J. Freshwater Biol. 7(3): 165-167.

Saron, T. and Bijen Meitei, L. (2013). Seasonal variation in zooplankton population with reference of water quality of Lril river in Imphal. Current World Environment. 8(1): 133-141

Schwoerbel, G. (1970). Methods of Hydrobiology (Freshwater Biology) Pergman Press: 200 pp.

Sharma, J. (1999). Effect of industrial wastes and sewage on abiotic and biotic (plankton and macrophyte) components of Behlol nullah, Jammu. Ph. D. Thesis, University of Jammu, Jammu.

Sharma, A. (2009). Hydrobiology of river Basantar at Samba. Ph. D Thesis University of Jammu, Jammu.

Sharma, S. , Kaushik, S. and Mathur, R. (1989). Pollution studies of Saank, Asaun and Kauri rivers in Madhya
Pradesh. In Management of ecosystems . U. P. Agarwal, B. N. Desai and S. A. H. Abidi (Editors) Narendra Publishing House Delhi. 211-218.

Sharma, P., Sood, A., Sharma, S., Bisht, S., Kumar, V., Pandey, P., Gusain, M. P. and Gusain, O. P. (2010). Bacterial indicators of faecal pollution and physiochemical assessment of important North Indian lakes. RMZ-Mate. \& Geoenviron., 57: 25-40.

Sharma, S. Bajracharya, R. M. , Situala, B. K. and Merz, J. (2005). Water quality in the central Himalaya. Current Sci.81: 774-784.

Slathia, D. Dutta, S.P.S. (2013) Hydrobiological study of a subtropical Shivalik Lake, Jammu, J \&K (India). Environmental and Biological Sciences,1(1): 143148

Vass, K.K., Raina, H.S., Zutshi, D.P. and Khan, M.A. (1977). Hydrobiological studies of river Jhelum. Geobios., 4(6): 238-248.

Vashisht, H.S. (1984). Bioindicators of waste waters. Paper presented in the seminar on "Status of Environmental Pollution in Punjab", held on November, 1. 1984 at PAU. Ludhiana: 62-64.

Vasisht, H.S. and Sra, G.S. (1979). The biological characteristics of Chandigarh waste waters in relation to physic-chemical factors . Proc. Sym. Env. Biology : 429-440.

Verma, S.R. and Dalela, R.C. (1975). Studies on the pollution of Kalinadi by industrial wastes near Mansurpur, part II. Biological index of pollution and biological characteristics of the river. Acta Hydrochim. Hydrobiol., $\underline{3}$ : 252-274.

Welch, P.S. (1948). Limnological Methods.Published by McGraw Hill Book Co. Inc. New York.

Welch, P.S. (1951). Limnology Reprint 2010. Narendra Publishing House Delhi-110006 (India)

Wetzel, R.G. (2000).Limnology. Lake and River Ecosystems. 3rd Ed. Academic Press: 841pp.

WHO (1991). The bacteriological quality of drinking. In : Guidelines for drinking water quality Vol. 2. Health criteria and other supporting information. Publ. by CBS Publishers and Distributors, Delhi.

Young, G.W. (1945). A limnological investigation of perihyton in Douglas lake, Michigan. Trans. Am. Micr. Soc. , 64: 1-20.

Zutshi, N. (1992). Effect of Jammu city sewage on abiotic and biotic factors of the river Tawi, Jammu.Ph. D. Thesis, University of Jammu, Jammu; 307pp. 